\title{
Urgensi Bermain Sebagai Stimulasi Perkembangan Otak Dan Solusi Mengatasi Kekerasan (Child Abuse) Dalam Pertumbuhan Dan Perkembangan Anak
}

\author{
Warni Djuwita ${ }^{1}$
}

\begin{abstract}
Abstrak: Usia emas, usia stimulasi fungsi otak. otak tumbuh sangat pesat mencapai 70-8\% diawal kehidupan anak, bayi 3 bulan ojtaknya telah membentuk koneksi yang jumlahnya 2 kali orang dewasa sekitar 1000 triliun melalui berbagai aktivitas visual, auditori, sensori dan motori Neurobiologis perkembangan otak dipicu oleh stimulasi dan pengalaman-pengalaman baru ${ }^{1}$ Silberg cara terbaik untuk mengembangkan jaringan hubungan pada otak anak kecil adalah dengan memberinya apa yang dibutuhkan, yakni suatu lingkungan yang menarik untuk dijelajahi, yang aman, dipenuhi dengan orang-orang yang merespons kebutuhan emosional maupun intellektualnya, yakni melalui program bermain ${ }^{2}$.

Musfiroh Tadkiroatun Stimulasi lingkungan ibarat pahatan yang bekerja membentuk sel-sel otak sehingga otak dapat berkembang dengan baik. Stimulasi yang menyenangkan, yang memberikan keleluasaan anakuntuk bereksplorasi melalui kegiatan menyanyi, menari, melukis, atau kegiatan bermain lainnya (Erikson, 1990, dalam Gutama. 2003) ${ }^{3}$. dalam bermain ada penyaluran bagi energi emosional yang terpendam, bermain merupakan sarana bagi anak untuk menyalurkan ketegangan atau traumatik (kekerasan) yang disebabkan oleh pembatasan lingkungan terhadap prilaku mereka. Melalui program bermain, solusi untuk menetralisir, memori bawah sadar anak, untuk tidak menjadi catatan-catatan buruk (child abuse) yang terbawa hingga dewasanya dalam agamapun bergerak dan bermain itu tersirat dalam Sabda Rosulillah Saw " keringat anak kecil menambah kecerdasannya diwaktu dewasa" (HR. AT-Tarmidzi) ${ }^{4}$
\end{abstract}

Kata Kunci: Otak, Bermain, Child Abuse, Pertumbuhan \& Perkembangan Anak

1 Dosen pada Fakultas Tarbiyah dan Ilmu Keguruan UIN Mataram

2 Bredekamp, Sue dan Copple, Carol Depelopmentally Approriate Practise in Early Chlmilhlmood Program (USA NAECY) hlm 75

3 Soegeng Santoso, Pendidikan Anak Usia Dini, (penerbit Citra Pendidikan Jakarta 2004 ) hlm 11

4 HLMainstoock.G. Elizabethlm, Metode Pembelajaran Montessori Untuk Anak Pra Sekolahlm (Jakarta; Pustaka delapratasa, 1999), hlm 10-11 


\section{PENDAHULUAN}

Usia Dini, Usia Emas, satu tahapan usia, sepanjang usia manusia yang sangat menentukan wujud pertumbuhan, perkembangan dan kepribadiannya. anak usia dini merupakan kelompok manusia yang berada dalam proses pertumbuhan dan perkembangan secara terus menerus dan merupakan masa yang berada pada rentang usia 0-8 tahun. ${ }^{5}$.

Soegeng Santoso ....... ”Anak usia dini sejak dalam kandungan (pendidikan anak usia dini secara tidak langsung), masa bayi hingga anak berumur kurang lebih 8 tahun, sampai usia SD Kelas Awal, kelas I/II/III, dan materi-materi kegiatannya adalah;

\section{USIA DINI, USIA PERKEMBANGAN EMAS OTAK MANUSIA,}

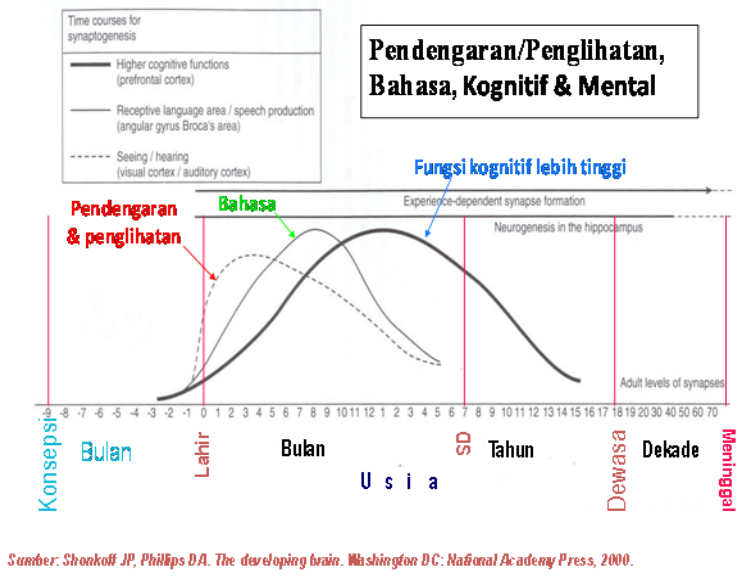

berhubungan dengan agama, budipekerti, etika, moral, toleransi, keterampilan, gotong royong, keuletan, kejujuran dll. Jika pelaksanaan pendidikan usia dini dapat berjalan dengan baik, maka proses pendidikan pada usia sekolah, usia remaja, usia dewasa, dstnya juga akan baik, maksudnya adalah, bahwa keberhasilan pendidikan itu tergantung pada pendidikan anak usia dini"'.

Masa usia dini merupakan masa yang sangat fundamental bagi kehidupan, dimana pada masa ini proses perkembangan berjalan dengan pesat. Montessori dalam Hainstock mengatakan bahwa masa ini merupakan periode sensitif (sensitive periods), selama masa inilah anak secara khusus mudah menerima stimulus-stimulus dari lingkungannya ${ }^{7}$. Pada masa ini anak siap melakukan berbagai kegiatan dalam rangka memahami dan menguasai lingkungannya. Selanjutnya Montessori menyatakan

5 Bredekamp, Sue dan Copple, Carol Depelopmentally Approriate Practise in Early Chlmilhlmood Program ( USA NAECY) hlm 75

6 Soegeng Santoso, Pendidikan Anak Usia Dini, (penerbit Citra Pendidikan Jakarta 2004 ) hlm 11

7 HLMainstoock.G. Elizabethlm, Metode Pembelajaran Montessori Untuk Anak Pra Sekolahlm (Jakarta; Pustaka delapratasa, 1999), hlm 10-11 
bahwa usia keemasan dimana anak mulai peka untuk menerima berbagai stimulasi dan berbagai upaya pendidikan dari lingkungannya baik disengaja maupun tidak disengaja. Pada masa peka inilah terjadi pematangan fungsi-fungsi fisik dan psikis sehingga anak siap merespon dan mewujudkan semua tugas-tugas perkembangan yang diharapkan muncul pada pola perilakunya sehari-hari ${ }^{8}$.

Usia Emas, Usia stimulasi fungsi otak, tiga tahun pertama kehidupan anak mempunyai IQ 20 poin lebih tinggi dibanding mereka yang kurang menerima stimulan. 3 th pertama dalam kehidupan anak merupakan masa yang paling sensitif, yang akan menentukan perkembangan otak dan kehidupannya dimasa mendatang. Otak tumbuh sangat pesat mencapai 70-80\% diawal kehidupan anak, bayi 3 bulan otaknya telah membentuk koneksi yang jumlahnya 2 kali orang dewasa sekitar 1000 trilliun melalui berbagai aktivitas visual, auditori, sensori dan motori.

Child Abuse, pengalaman-pengalaman traumatis masa kanak-kanak (salah asuh ) mengakibatkan otak gagap. Berbagai prilaku menyimpang, seperti; kepribadian ganda, paranoid, sifat agressif, gangguan-gangguan emosi dalam berbagai bentuknya adalah cerminan dari otak yang gagap (otak yang tumbuh secara tak terstruktur sebagai akibat "child abuse" kekerasan kata para ahli, para pejuang perlindungan anak dan perempuan, bahwa sebagain besar kekerasan ( hingga 70-80 \%) terjadi dalam rumah tangga, berikutnya sekolah dan lingkungan masyarakat. Beberapa bentuk kekerasan yg terjadi di dalam keluarga, seperti pengabaian anak, kekerasan fisik, plecehan emosional/psikologis, dan plecehan seksual anak. Melalui program bermain, sebagai pendekatan dan solusi untuk menetralisir, memory bawah sadar anak, untuk tidak menjadi catatn-catatan buruk yg terbawa hingga dewasanya. Bahwa Play in every culture. play in every language. Play every where-the children of the world play ${ }^{9}$ Bermain menjadi pekerjaan dan keseharian anak, dimana dan kapan saja. Prof Conny R,Semiawan, bermain merupakan salah satu kebutuhan dasar anak,jika tidak terpenuhi, ada suatu tahapan perkembangan yang berfungsi kurang baik yang akan terlihat kelak jika sianak sudah menjadi remaja/dewasa ${ }^{10}$

\section{Bermain, stimulasi Perkembangan Otak}

Stimulasi sangat penting untuk tumbuh kembang anak, berfungsi membantu meletakkan kemampuan dasar kearah optimalisasi perkembangan sikap dan prilaku positif serta seluruh potensi lainnya yang dimiliki anak, juga memberikan program yang tepat bagi anak sesuai kondisi potensi yang dimiliki anak. Bahwa perkembangan

\footnotetext{
8 HLMainstock, Ibid, hlm 34

9 Bronson, Marthlma B. thlme Righlmt Stuff For chlmildren birt to 8. selecting Play Materials to support

10 R Conny Semiawan, opcit hlm
} 
awal bagi seorang anak merupakan peletak dasar bagi perkembangan selanjutnya. Anak yang mendapat stimulasi yang tepat dan terarah akan lebih cepat berkembang dibandingkan anak yang kurang atau bahkan tidak distimulasi Essa "When young children do not have such experiences, particullary consisten and predictable care, they cannot fully develop that built-in template for relationships. They do not have that special one or two people who deeply care about them. They may never feel fully safe, because they have not developed a strong, trusting relationship with someone they can totally rely on. Such children may grow up never experiencing deep relationships, only relating to others on a shallow level. Lack of a strong, secure attachment to at least one caring adult can result in a child living in an uneasy or stressful state because needs are never satisfsctory met " 11

Senada dengan ungkapan Sujatmiko bahwa untuk dapat melihat perkembangan kecerdasan anak memerlukan beberapa aspek, antara lain terpenuhinya kebutuhan biomedis, kasih sayang, dan stimulasi. ${ }^{12}$ Tiga tahun pertama dalam kehidupan anak merupakan masa yang paling sensitif, yang akan menentukan perkembangan otak dan kehidupannya dimasa mendatang. Otak tumbuh sangat pesat diawal kehidupan anak, hingga mencapai $70-80 \%$, bayi 3 bulan otaknya telah membentuk koneksi yang jumlahnya kurang lebih 2 kali orang dewasa sekitar 1000 trilliun. Dan koneksi akan semakin kuat terbentuk sangat tergantung pada stimulasi. Vasta, otak janin itu bertumbuh lebih cepat dari organ manapun, hal ini berlanjut di awal masa kanakkanak, pada saat kelahiran berat tubuh bayi 5\% dari berat orang dewasa, sedang otak $25 \%$ setelah tiga tahun usia otak sudah mencapai $80 \%$, bandingkan dengan $20 \%$ dengan berat tubuh (Morgan, \& gibson, 1991; Tanner,1990) ${ }^{13}$

Mayza masa usia dini merupakan priode emas untuk melakukan proses stimulasi aktif yang disesuaikan dengan pertumbuhan fisik otak dari sejak lahir ${ }^{14}$. Sehubungan dengan potensi kecerdasan yang dibawa anak sejak lahir tidaklah akan berarti apaapa apabila lingkungan tidak memberikan stimulus. Otak yang selalu diberi stimulus akan semakin memperbanyak dan memperkuat jaringan sel neuronnya dan sebaliknya apabila tidak mendapat stimulus maka pertumbuban otak akan berhenti sama sekali. Stimulasi yang diterima saat ini sangat berpengaruh terhadap perkembangan pada priode berikutnya saat remaja, dewasa dan malah saat tua. Priode emas ini berlangsung hanya sekali saja, apabila terlewatkan, berarti tak ada kesempatan lagi untuk mengulanginya.

11 Essa, Ibid, hlm 41

12 Auryn Virzara, HLMow to creat a Smart kids, Seri Kecerdasan anak, ( penerbit Katahlmati.2007), hlm 9-23

13 Vasta, Marshlmall M HLMaithlm, . Miller A Scott, chlmild psychlmology,(Thlme modern Science 1999). hlm 178

14 Mayza, Stimulasi Otak Pada Anak Usia Dini, Seminar dan Lokakarya Nasional PAUD UNJ (Jakarta dari tgl 8-12 Oktober 2004 ) hlm 70 
Essa, pengembangan yang sangat cepat dari sel-sel otak adalah pada masa kanak-kanak, belajar sebagai hasil koneksi-koneksi di dalam otak. Pengembangan bahasa, emosi, sangat cepat pada tahun pertama dan pengembangn cognitif mencapai puncaknya pada dua sampai tiga tahun pertama dari kehidupan ${ }^{15}$.

Dan Neurobiologis menjelaskan, perkembangan otak dipicu oleh stimulasi dari pengalaman-pengalaman baru $^{16}$. Pengalaman-pengalaman traumatis masa kanakkanak dari lingkungan akan sangat mempengaruhi tentang kesejahteraan masa depan mereka. Semakin muda si anak diberi latihan-latihan yang dapat mengembangkan pertumbuhan otaknya, semakin pintar ia kelak. Memulai latihan pada usia 5 tahun itu sangat terlambat

Pertumbuhan otak yang sangat cepat dan pesat terjadi sebelum usia satu tahun. Secara faktual lebih dari 100 ribu sel diperkirakan terdapat di dalam gen manusia dipergunakan untuk memproduksi sel-sel otak. Bayi yang baru lahir mempunyai milliaran sel otak, jauh lebih banyak dari yang mereka dapatkan pada usia tiga tahun dan dua kali lebih banyak dari sel-sel otak orang dewasa ${ }^{17}$ Dalam Osborn, White dan bloom diungkapkan:

1. Saat lahir bayi memiliki sekitar 100 milyar sel otak yg belum saling bersambungan.

2. Banjir pengalaman indera yang diterima anak akan memperkuat dan memperbanyak sambungan antar sel (sinapsis).

3. Kerja otak sangat efisien, bagian yang tidak digunakan akan dimusnahkan (athrophy).

4. Satu sel otak dapat bersambungan dengan 15.000 sel otak lain.

5. Saat berusia 3 th, sel otak telah membentuk sekitar 1.000 triliun jaringan koneksi, jumlah ini 2 kali lipat dari yg dimiliki orang dewasa

6. Banyaknya sambungan antar sel akan menentukan tingkat kompleksitas kemampuan berpikir (kecerdasan) seseorang.

7. Perkembangan kecerdasan terjadi sangat pesat di awal kehidupan anak: 50\% pada usia 0-4 th dan 50\% sisanya pada rentang usia 4-18 th.

Tentang Otak Jalaludin Rahmat mengungkap, Otak mengatur seluruh fungsi tubuh, mengendalikan kebanyakan prilaku dasar manusia, makan, tidur, menghangatkan tubuh, otak bertanggung jawab atas semua kegiatan manusia yang

15 Essa, Introduction To Early Chlmildhlmood Education (4thlm ed, University of Nevada, Reno. 2003) hlm 40

16 Essa, ibid. hlm 40

17 Oberlander, Slow And Steady Get me Ready, (alihlm bahlmasa soesanti HLMarini HLMartono)( PT Primamedia Pustaka 2005). hlm iii 
sangat canggih, menciptakan peradaban, musik, seni, ilmu, dan bahasa. Harapanharapan, pikiran, emosi, dan semua kepribadian ${ }^{18}$. Hendrawan Nadesul Orang dapat hidup tanpa prostat, tanpa rahim ,jantung, limpa, usus namun tak mungkin tanpa otak, otak manusia ibarat kaset lagu dari luar tampak sama, dan akan dikenal siapa seseorang setelah kaset dikepalanya diputar, tiap orang punya lagu yang berbeda, martabat seseorang ditentukan oleh isi lagu di otaknya ${ }^{19}$. Brain growth Spurt, kata Sidiarto Kosomoputro \& Lily

"Bahwa laju perkembangan otak amat pesat dimulai sejak dalam kandungan, hingga berjumlah 250000 sel neuron baru tumbuh setiap menit mencapai 200 milliar saat gestasi/pembuahan berusia 20 minggu (jumlah puncak yang diperoleh seumur hidup) sel-sel otak tumbuh terus sampai umur 2th, setelah itu terhenti dilanjutkan oleh pertumbuhan jaringan koneksi antar sel. Laju cepat pertumbuhan otak ini dibuktikan dengan berat otak yang semakin bertambah, 4-2th dari 50 gr menjadi 400 gr, menjadi 1000 gr pada usia 18 bulan. Penambahan berat otak disebabkan oleh pertumbuhan sinaps-sinaps sel yang membentuk jaringan antar sel, yang dipacu oleh rangsangan lingkungan dan pengalaman (stimulasi) dalam bukunya yang lain juga diungkapkan, bahwa otak bukan organ yang statis, tetapi dinamis yang senantiasa tumbuh dan berkembang membentuk nerve cell connection (jaringan antar sel) yang baru, dan itu sangat dipengaruhi oleh rangsangan atau stimulus dari dunia luar (environment) ${ }^{\prime 20}$

Dalam Slee \& Shute bahwa struktur otak ditentukan oleh proes-proses yang epygenetic dan anak memiliki koneksi synaptic yang sangat banyak di dalam kortec otak besar dibanding anak setelah besar/dewasa ${ }^{21}$. Bagi penganut materialis seperti ahli jiwa Freud, otak manusia adalah segala-galanya. Ia refleksi jiwa, cermin kepribadian, konon tempat roh bermukim. Otak menentukan niat, pikir, emosi, dan laku kita, apa yang kita pikir, rasa, dan putuskan merupakan hasil kerja milliaran sel otak, jutaan rangkaian kabel, dan terminal-terminal listrik yang menyusunnya ${ }^{22}$.

Kemampuan otak dapat terus ditingkatkan melalui belajar. Karena itu para ahli neuroscience menekankan, bahwa, dimasa awal dari pertumbuhan manusia, kualitas kemampuan otak dalam menyerap informasi sangat tergantung dari banyaknya neuron yang membentuk unit-unit. Dimana unit-unit neuron sangat ditentukan

18 Jalaludin Rachlmmat, Belajar Cerdas, Belajar Berbasiskan Otak, (Penerbit MLC. edisi hlmusus 2005) hlm 5

19 Taugada, Memahlmami Otak, (Penerbit Kompas Jakarta 2003).hlm ix-x

20 Lily Djokosetio Sidirto, Perkemangan Otak dan Kesulitan belajar, (Universitas Indonesia, 2007) hlm 4

21 Slee phlmilip nand Shlmute Rosalyn, chlmild Development: thlminking about thlmeories, ( Oxford University press Inc, New york 2003). hlm 39

22 Taugada, Buku Kompas, locsit. hlm ix-x 
oleh stimulasi dari luar ${ }^{23}$. Impilakasi ketika anak tidak mendapatkan lingkungan yang merangsang pertumbuhan otak, maka secara pisik pengembangan otaknya akan lebih kecil hingga 20-30 \% dari ukuran normal anak seuasianya. Bahkan ketika fase emas yang datangnya Cuma sekali dalam rentang kehidupan manusia apabila terlewatkan secara sia-sia (tanpa stimulasi epektif \& edukatif), maka lenyaplah pula peluang untuk berkembang pada fase selanjutnya, dalam istilah se-hari-hari diungkap dalam istilah " Anak Yang Kehilangan Masa kecil"24

Soemarmo dkk dalam makalahnya, bahwa "brain cause mind" (otaklah yang menimbulkan pikiran), yakni ada hubungan antara informasi yang ditangkap indra dengan kemampuan otak untuk mengolahnya, Use it or loose it, konsep yang mengatakan semakin otak digunakan, akan semakin berperan, makin ia didiamkan, semakin kehilangan fungsi luhurnya ${ }^{25}$. Selama masa perkembangannya otak terus mengalami perubahan-perubahan sesuai dengan stimulasi yang diterima melalui seluruh panca indria, hal ini pulalah yang akan mempengaruhi tingkat kecerdasan, kepribadian dan kualitas hidup seorang anak.

Bahwa stimulasi sangat penting bagi perkembangan dapat juga dilihat dari sisi keberadaan gen pada tubuh sejak awal pertumbuhan manusia, hal ini sebagaimana terungkap dalam penjelasan Jensen.... " bahwa manusia memiliki 25.000 gen, di samping juga memiliki 50 trilliyun sel. Dimana situs-situs reseptor (yang menerima informasi) sel itu diaktipkan oleh keadaan2 tertentu, seperti terang atau panas dsbnya, selain itu situs-situs reseptor tersebut tidak hanya mengolah informasi, tetapi juga memiliki kegiatan aliran elektrokimia yang pada ahirnya mempengaruhi gen-gen. Artinya bahwa ribuan gen itu bersifat responsif terhadap sinyal-sinyal lingkungan, maka selain gen yang menjadi kekuatan kehidupan, juga karena adanya kekuatan pengaruh lingkungan (stimulasi lingkungan)"26

Kebenaran penjelasan di atas sebagaimana juga terungkap berdasar pengakuan paham Nativisme bahwa ketika anak dilahirkan telah memiliki blue print berupa bakat sebagai potensi genetis yang dibawa sejak lahir, dan anak berkembang secara alami, mengikuti keumuman tahap pengembangan setiap anak, namun Gaseli (kaum Nativis) mengakui bahwa lingkungan memiliki peranan penting dalam mengembangkan kemampuan bawaan ${ }^{27}$.

\footnotetext{
23 Sidiarto Kusumoputro, Lily Sidiarto Djokosetio, opcit, hlm 4-6

24 Sidiarto \& Lily, ibid hlm 6

25 Dirjen PLS, Direktur PAUD, Jurnal Ilmiyahlm PAUID, (edisi 02, Thlm2002, Jakarta), hlm 3

26 Jansen, Memperkaya Otak, Cara Memaksimalkan Potensi setiap Pembelajar, (PT Macanan Jaya Cemerlang, 2008), hlm 4-5

27 Forum PAUD, Potret Pengasuhlman, Pendidikan, dan Pengembangan Anak Usia Dini di Indonesia, (Jakarta 2004) hlm 4-5
} 
$V$ asta bahwa anak-anak menerima warisan $50 \%$ dari gen-gen orang tua mereka, sehingga jika terjadi kesamaan diantara keluarga ${ }^{28}$, bukan sesuatu yang mengejutkan, hal itu karena memiliki kesamaan "basic genetic Sigmund Freud pada abad sembilan belas pertama kali mempopulerkan bahwa pengalaman anak-anak awal adalah penting bagi perkembangan ahir invidual. Jika pada usia tersebut orang dewasa tidak melakukan apa-apa (stimulasi) terhadap anak maka dapat diramalkan anak akan menemukan kesulitan di masa-masa selanjutnya. ${ }^{29}$

John Locke...... "ketika bayi dilahirkan, dia seperti tabula rasa atau kertas kosong, pikiran seorang anak merupakan hasil dari pengalaman dan proses belajar. Beberapa pokok ajaran John Locke, yakni: (i) Individu memiliki tempramen yang berlainan, namun secara keseluruhan lingkunganlah yang membentuk pikiran seseorang, (ii) Hal yang paling penting adalah proses belajar pada masa bayi, (iii) Lingkungan menentukan cara berfikir seseorang melalui asosiasi antara pikiran dan perasaan, (iv) Banyak prilaku manusia yang berkembang berdasarkan proses repetisi atau pengulangan, (v) Manusia mengalami proses belajar melalui imitasi atau peniruan, (vi) Manusia belajar melalui reward and punishment atau imbalan dan hukuman. Perkembangan berikutnya dari kelompok Interaksionis"30

Gunawan lingkungan yang kaya dengan multi sensori serta tantangan berfikir (stimulus multi), akan menghasilkan jumlah koneksi yang lebih besar di antara selsel otak ${ }^{31}$. Gredler daya untuk memunculkan atau memicu suatu respon tertentu ${ }^{32}$. Mayza Simulasi berkaitan dengan mengoptimalkan seluruh kemampuan modalitas otak, seperti pelihat (visual), pendengaran, sensomotorik yang dikaitkan dengan peningkatan kemampuan kognitif ${ }^{33}$. Essa bahwa pengembangn yang sangat cepat dari sel-sel otak adalah pada masa kanak-kanak, dan belajar adalah hasil koneksi-koneksi di dalam otak. Pengembangan bahasa, emosi, sangat cepat pada tahun pertama dan pengembangn cognitif mencapai puncaknya pada dua sampai tiga tahun pertama dari kehidupan ${ }^{34}$.

Gagal memberikan stimulasi atau rangsangan pada usia awal sangat sukar untuk diubah atau diarahkan kelak di kemudian hari. Brenice Weissbourd (1998) bahwa semua anak memerlukan dan sepatutnya memiliki hubungan yang berkesinambungan dengan orang dewasa yang secara konsisten memperhatikan dan mengurus mereka,

28 Vasta, Opcit, hlm 102

29 Time Life Asia, Developing Your Chlmild's Potensial, successful Parenting (Printed in Cina, 2000), hlm 2

30 PWiwin Dinar Prastiti, Psikologi Anak Usia Dini, ( Macanan Jaya Cemerlang Bogor, 2008 ) hlm 3-4

31 Gunawan, Opcit hlm 9

32 Margaret E. Bell Gredler, Belajar dan membelajarkan, (CV Rajawali,1991), hlm 115

33 PASCASARJANA UNJ, Prodi PAUD bekerja sama dengan Direktorat PAUD, Laporan Eksekutif SEMILOKA PAUD, (2004) hlm 70

34 Essa, Opcit hlm 40 
yaitu orang-orang yang sangat mencintai mereka, yang memperlakukan mereka secara husus, memberikan stimulasi dan memelihara mereka. ${ }^{35}$

Musfiroh Tadkiroatun untuk memaksimalkan kecerdasan anak, stimulasi harus diberikan sejak tiga tahun pertama kehidupannya. Stimulas $i$ lingkungan ibarat pahatan yang bekerja membentuk sel-sel otak sehingga otak dapat berkembang dengan baik. Stimulasi yang menyenangkan, lingkungan yang memberikan ketenangan dan penuh kasih sayang, lingkungan yang memberikan keleluasaan anak untuk bereksplorasi melalui kegiatan menyanyi, menari, melukis, atau kegiatan bermain lainnya akan membuat anak memiliki perkembangan otak kanan yang baik, sesuai dengan fungsi belahan otak kanan mengurusi perkembangan emosi dan kreativitas, maka anak yang mendapat stimulasi lingkungan dan pendidikan yang tepat di usia dini tumbuh menjadi anak yang percaya diri, berani tampil, mampu bekerjasama, menghargai pendapat orang lain, saling menolong dan bertanggung jawabatas perbuatan yang dilakukan (Erikson, 1990, dalam Gutama, 2003)"36.

Silberg Cara terbaik untuk mengembangkan jaringan hubungan pada otak anak kecil adalah dengan memberinya apa yang dibutuhkan, yakni suatu lingkungan yang menarik untuk dijelajahi, yang aman, dipenuhi dengan orang-orang yang merespons kebutuhan emosional maupun intellektualnya ${ }^{37}$.

Jensen mengungkap ${ }^{38}$ Sekarang ini banyak anak tidak mendapatkan stimulasi motorik awal yang diperlukan, anak di asuh oleh televisi, didudukkan dalam kursi roda, atau diikatkan pada sabuk pengaman mobil selama ratusan jam, sementara anak yang sedang tumbuh harus mendapatkan beragam input untuk merangsang pertumbuhannya, termasuk banyak latihan memegang benda-benda, mempelajari bentuk, berat dan gerakan melalui berbagai variasi permainan. Walau anak-anak memerlukan sebanyak mungkin informasi, tapi tidak dari televisi, karena televisi tidak memberikan waktu dan kesempatan bagi anak untuk melakukan reflexi, interaksi, atau pengembangan visual tiga dimensi. Dan dengan tidak menonton televisi, otak anak akan memiliki lebih banyak waktu untuk mengembangkan keahlian bahasa, sosial, dan motoriknya secara lebih baik".

Raine dalam penelitiannya terhadap 1795 anak usia 3 tabun yang paling pemberani tentang kegiatan eksplorasi dan petualangan2 melalui bermain, bahwa eksplorasi sangat penting, mengisyaratkan kecintaan anak terhadap pembelajaran, pemenuhan

35 Dirjen PLS, Direktorat PAUD, Jurnal Ilmiyahlm PAUD, vol 2 No 01,( April 2003), hlm

36 Musfirahlm, Bermain Sambil Belajar dan Mengasahlm Kecerdasan (Depdiknas Jakarta 2005) hlm 8

8

37 Silberg, Brain Games for Toddlers (alihlm bahlmasa, Nike sinta Karina)( Penerbit Erlangga 2004) hlm

38 Jensen, Merperkaya Otak, Cara memaksimalkan Potensi Setiap Pembelajar, (PT Indeks Jakarta, 2008) hlm 243246 
rasa ingin tahu alami dan untuk proses 2 penemuan, anak-anak tersebut mendaptkan nilai 12 poin lebih tinggi di atas IQ total ketika mereka diuji setahun berikutnya. Mereka juga memiliki kemampuan akademis dan membaca jauh lebih baik melebihi teman-teman sebayanya yang kurang eksplorasi dan kurang terpenuhi rasa ingin tahunya ${ }^{39}$

Eksplorasi dan kegiatan fisik mengembangkan otak lebih baik daripada berdiam diri. Sebuah kehidupan aktif pada dua tahun pertama dapat meningkatkan sistem vestibular. Sistim ini merupakan mekanisme dalam telinga yang bertanggung jawab atas keseimbangan yang harus diaktifkan sedini mungkin. kegiatan-kegiatan seperti berguling, berputar, melingkar, meluncur, melompat, berayun dan permainanpermainan anak lainnya, sangat bermamfaat dalam membangun otak yang sedang berkembang.

Palmer dalam program inovatifnya pada anak prasekolah mengungkap, bahwa kurangnya rangsangan vestibular, yakni merangsang sistem sensorik anak-anak untuk mengembangkan tingkat keberhasilan akademik yang lebih tinggi mengakibatkan munculnya persoalan 2 pembelajaran, seperti membaca, menulis dan matematika, ${ }^{40}$. Selama lebih 20 tahun Palmer telah menunjukkan bahwa rangsangan motorik dini dapat membuat pemusatan perhatian, keterampilan mendengar, nilai membaca, dan keterampilan menulis menjadi lebih baik, bagaimana menciptakan tanggapan pengayaan di dalam otak yang sedang berkembang ? Eksplorasi dan gerakan aktif, terkendali dan aman adalah jawabannya. Bermain dan bergembira, jauh dari tindak kekerasan, dan dalam suasana penuh kasih sayang adalah memberi kemungkinan besar bagi optimalisasi perkembangan semua kecerdasan anak, dungkapan Seto Mulyadi pada seminar di Hotel Bidakara, jakarta pertengahan 2006 $6^{41}$

\section{Bermain, Stimulasi Aspek - Aqspek Perkembangan Anak}

Dalam sebuah tulisan diungkapkan, bahwa Indonesia urutan terendah dalam riset kemampuan Fisik dan bermain anak ${ }^{42}$ informasi ringkas hasil penelitian tersebut adalah, hasil riset Play and Phisical Quotient (PQ) atau riset kemampuan fisik dan bermain anak, dimana anak-anak Indonesia dalam hal kesehatan fisik menempati urutan terendah dibandingkan dengan Thailand, Vietnam dan jepang.

39 Jensen, ibid, hlmal 246

40 Jansen, ibid, hlm 247

41 MISI, Dirjen PMPTK. Majalahlm Pendidik dan tenaga Kependidikan Pendidikan Non Formal, edisi ke 2/vol 01/ april 2007. hlm 43

42 Lukman Sriamin, Indonesia Urutan Terendahlm Dalam Riset Kemampuan Fisik Bermain Anak, hlm 1. hlmttp:/ hlmimpsijaya.org/2006/07/07 
Anak adalah makhluk yang aktif dan dinamis. Kebutuhan-kebutuhan jasmaniah dan rohaniahnya sebagian besar dipenuhi melalui bermain, baik bermain sendiri maupun bersama-sama dengan teman. Jadi, bermain itu merupakan kebutuhan anak. The Charter of Children's Right (1989). Bahwa setiap anak di dunia ini mempunyai hak untuk bermain ${ }^{43}$. Ahli-ahli pendidikan menganggap bermain sebagai kegiatan yang mempunyai nilai praktis artinya bermain digunakan sebagai media untuk meningkatkan ketrampilan dan kemampuan tertentu pada anak. Bermain merupakan jembatan bagi anak dari belajar secara informal menjadi formal

Pentingnya kegiatan bermain bagi pengembangan kemampuan anak sudah disadari oleh para ahli filsafat seperti Plato maupun Aristoteles. Aristoteles berpendapat bahwa anak-anak perlu didorong untuk bermain dengan apa yang akan mereka tekuni dimasa dewasa nanti ${ }^{44}$. Bermain merupakan kegiatan pokok anak. Dengan bermain anak akan memperoleh pengetahuan dan pengalaman yang membantu perkembangannya untuk menyiapkan diri dalam kehidupan selanjutnya. Melalui kegiatan bermain anak bisa mencapai perkembangan fisik, intellektual, emosi, sosial dan bahasanya.

Permainan memberikan sumbangan yang besar pada perkembangan anak, melalui permainan anak-anak belajar; tentang gagasan-gagasan, tentang hubunganhubungan, tentang moral, tentang perasaan. diri sendiri maupun orang lain ${ }^{45}$ Bermain bukan hanya menjadi kesenangan tetapi juga suatu kebutuhan yang mau tidak mau harus terpenuhi, karena jika tidak terpenuhi menurut conny R. Semiawan ada suatu tahapan perkembangan yang berfungsi kurang baik yang akan terlihat kelak jika sianak sudah menjadi remaja ${ }^{46}$

Reni Kusumowardani dari Himpsi Jaya, ada persepsi yang keliru dari para orang tua di Indonesia, orang tua masih menganggap ngapain sih main melulu, mendingan juga les ungkapnya ${ }^{47}$, bahwa bermain adalah jendela perkembangan anak. lewat bermain justru semua aspek perkembangan anak bisa ditumbuhkan secara optimal dan maksimal. Bahwa untuk mengembangkan IQ, EQ dibutuhkan modal dan ternyata dari hasil penelitian, modal yang paling tepat adalah lewat kegiatan bermain, lewat kegiatan bermain anak-anak akan belajar tenggang rasa, tahu aturan serta pengembangan kemampuan kognitif anak.

\footnotetext{
43 Bruce, opcit, hlm 238

44 Mayke S. Bermain, Mainan Dan Permainan Untuk Pendidikan Anak Usia Dini, (Jakarta, Pt Gramedia, 2001) hlm.

45 Bruce, opcit hlm 240

46 R Conny Semiawan, opcit hlm

47 Lukman Sriamin, ibid hlm 2
} 1 
Demikian juga ungkapan dari Anggani Sudono banyaknya para orang tua yang berkata jangan main air, nanti masuk angin, jangan main pasir, itu kotor,jangan main saja, kapan mau belajar! Anak saya suka bermain, susah belajar ${ }^{48}$, bahwa semua ungkapan menunjukkan kurang fahamnya masyarakat tentang bermain, dipahami seakan bermain adalah sesuatu yang kurang baik,. Ketika bermain anak mengembangkan kepribadiannya, kekuatan dirinya muncul secara optimal, tindakan pengulangan yang dilakukan ketika bermain mengembangkan kemampuan logikanya. Bermain membuat anak kreatif, anak menggunakan imaginasinya, kesempatan untuk menemukan berbagai cara pemecahan masalah. ketika bermain anak merasa senang, tidak ada paksaan apapun, anak melakukan eksplorasi dengan spontan

NAEYC dalam "Guidelines for Developmental Appropriate Practice"? menegaskan bahwa peran bermain tidak hanya memberikan kontribusi pengembangan kognitif tetapi merupakan mata rantai yang vital dalam mendorong pertumbuhan dan perkembangan di semua aspek. Bermain bagi anak adalah pemilihan wahana dan indikator pertumbuhan mental mereka. Bermain memungkinkan anak-anak melalui proses perkembangan secara. urut. Dimulai dari perkembangan sensorimotor pada usia bayi, praoperasional untuk usia prasekolah, pemikiran operasional konkrit untuk sekolah dasar. Itu semua termasuk pengembangan kognitif sehingga bermain memiliki fungsi penting dalam pengembangan fisik, emosi dan sosial. ${ }^{49}$

Mengutip penyataan Essa bagi seorang anak, bermain adalah kebutuhan, sebagai sarana belajar ${ }^{50}$. Permainan penting untuk perkembangan semua aspek perkembangan anak. Permainan sebagai aktivitas terkait dengan keseluruhan diri anak, bukan sebagiannya, melalui permainan anak mempromosikan serta memperaktekkan penguasaan2 keterampilannya yang mengarahkan perkembangan kognitif anak, perkembangan bahasa, mengarahkan perkembangan fisik. Membantu anak dalam mengembangkan kreativitasnya. Melalui pengembangn kreativitas peristiwa sosialisasi dan emosi anak juga berkembang, siklus aktivitas seperti itu adalah merupakan kegiatan yang sehat bagi anak-anak.

Saralea beberapa perinsip permainan berdasarkan prilaku pada saat anak anak bermain, antara lain; permainan itu sesuatu yang menyenangkan, diluar dari peristiwa se-hari-hari, sebagai sarana experiment berbagai hal, terbuka tanpa batas, permainan sesuatu yang aktif dinamis, tidak statis, muncul sebagai aktivitas-aktivitas yang

48 Anggi Sudono, Makalahlm Semiloka pada Forum Paud di NTB, Arti Bermain Dengan memamfaatkan Semua Bahlman Di Lingkungan Anak, 7 Agustus 2004

49 Bredekamp S, opcit, hlm 144

50 Essa, opcit hlm 41 
tidak dibatasi oleh ruang dan waktu ${ }^{51}$. Permainan sangat penting artinya bagi setiap anak disegala zaman, memiliki kontek hubungan sosial dan pembelajaran spontan, aktivitas bermain sebagai medium memahami dunia ini secara lebih baik, ekspressif, sebagai sarana komunikasi untuk melakukan pendekatan pendekatan, mengungkap perasaan2 dan pesan-pesan.

Bahwa dalam proses tumbuh kembang anak, maka bermain adalah merupakan salah satu kebutuhan dasar yang tidak boleh tidak harus terpenuhi, karena anak yang kurang terpenuhi kebutuhan-kebutuhan dasarnya, akan mengalami hambatan dalam perkembangannya, dan sering terjadi anak akan berkembang menjadi anak yang bermasalah. Sedangkan anak yang terpenuhi kebutuhan dasarnya akan tumbuh kembang menjadi anak yang sehat, lincah, jasmani, rohani serta memiliki rasa aman. Dengan bergerak dan bermain, ada nilai fisik dan kesehatan, yakni dengan permainan yang aktif anak-anak dapat mengembangkan fungsi otot-ototnya serta fungsi organorgan tubuhnya. Secara optimal.

Ada nilai Pendidikan/Kognitif, yakni melalui bermain anak belajar mengenal dan menguasai dunianya sesuai tahap perkembangannya. Ada nilai kreatif, yakni memberi kesempatan yang banyak pada anak dalam mengeluarkan idenya untuk memecahkan masalah pada setiap permainan. Ada nilai sosial emosional, yakni anak belajar mengenal dan membina hubungan dengan orang lain, menysuaikan diri, menerima, berbagi, mengendalikan emosi, seperti agresivitas, rasa kurang senang, rasa gembira dsb. Ada nilai moral, yakni bermain memberi sumbangan dalam pelatihan pembentukan moral belajar bersikap jujur, dan menerima kekalahan dan kemenangan dengan wajar

Hurlock bahwa melalui bermain; ada perkembangan fisik, yakni bermain aktif penting bagi anak untuk mengembangkan otot dan melatih seluruh bagian tubuhnya, juga sebagai penyaluran tenaga yang berlebihan yang bila terpendam akan membuat anak tegang, gelisah, dan mudah tersinggung ${ }^{52}$. Ada dorongan berkomunikasi, yakni agar dapat bermain dengan baik bersama teman, anak harus belajar berkomunikasi, dan atau sebaliknya, anak harus mengerti apa yang dikomunikasikan anak lain.

Dalam bermain ada penyaluran bagi energi emosional yang terpendam, yakni bermain merupakan sarana bagi anak untuk menyalurkan ketegangan yang disebabkan oleh pembatasan lingkungan terhadap prilaku mereka. Ada penyaluran bagi kebutuhan dan keinginan, yakni kebutuhan dan keingian yang tidak dapat dipenuhi dengan cara lain seringkali dapat dipenuhi dengan bermain, anak yang tidak mampu mencapai

51 Saralea E Chlmazan, opcit. hlm 19-20

52 HLMurlock, opcit. hlm 323 
peran pemimpin dalam kehidupan nyata mungkin akan memperoleh pemenuhan keinginan itu dengan menjadi pemimpin tentara mainan.

Ada sumber belajar, yakni bermain memberi kesempatan untuk mempelajari berbagai hal, melalui buku, televisi, atau menjelajah lingkungan, yang tidak diperoleh anak dari belajar dirumah atau disekolah. Ada rangsangan bagi kreativitas, yakni melalui eksperiment dalam bermain anak-anak menemukan bahwa merancang sesuatu yang baru dan berbeda dapat menimbulkan kepuasan. Selanjutnya mereka dapat mengalihkan minat kreatifnya kesituasi diluar dunia permainan.dengan bermain anak mengetahui tingkat kemampuannya dibandingkan dengan temannya bermain. Ini memungkinkan mereka untuk mengembangkan konsep dirinya dengan lebih pasti dan nyata.

Dalam bermain anak belajar bermasyarakat, yakni dengan bermain bersama anak lain mereka belajar bagaimana membentuk hubungan sosial dan bagaimana menghadapi dan memecahkan masalah yang timbul dalam hubungan tersebut. Anak belajar bermain sesuai dengan peran jenis kelamin, yakni anak belajar di rumah dan di sekolah mengenai apa saja peran jenis kelamin yang disetujui, akan tetapi mereka segra menyadari bahwa mereka juga harus menerimanya bila ingin menjadi anggota kelompok bermain. Ada perkembangan ciri kepribadian yang diinginkan, yakni dari hubungan anggauta kelompok teman sebaya dalam bermain, anak belajar bekerjasama, murah hati, jujur, sportif, dan disukai orang

Bermain itu menyenangkan, belajar liwat permainan memungkinkn seorang anak untuk belajar dengan cara alam, dimana kegembiraan menimbulkan semangat optimal, dengan dukungan dan bimbingan yang lembut, seorang anak kecil dapat merasa percaya diri untuk tidak menyerah ketika menghadapi rintangan pertama ${ }^{53}$.

Belajar tidak harus dilakukan dengan serius dan di dalam ruangan, dengan konsentrasi penuh, tetapi bisa dilakukan dengan cara bermain disesuaikan dengan tahap-tahap perkembangan, kemampuan dan prilaku anak. Karena anak-anak akan bermain dengan cara yang paling sesuai untuk hal-hal yang harus mereka pelajari ${ }^{54}$. Sebuah experimen pembelajaran yang dilakukan dengan metode Genius learning, pembelajaran dikemas melalui permainan, maka hasilnya dapat mempersingkat waktu belajar bingga $60 \% \%^{55}$.

\section{Bermain, pengembangan Nilai Kasih sayang, Pola Asuh Anak Usia Dini, Membebaskan Traumatik Anak.}

\footnotetext{
53 kemp \&Clare Walters, Brain Games, ( Karisma publishlming Group, Batam center, 2004) hlm 6

54 Sunar Prasettyono, Membedahlm Psikologi Bermain anak, ( Penerbit Thlmink Yogyakarta 2007) hlm 25-37

55 Gunawan Genius Learning Strategy, (PT Gramedia Pustaka Utama 2003) hlm 205-208
} 
Setiap anak terlahir fitrah, suci, berkarakter hanif, lurus, setiap anak lahir baik, tidak jahat dan setiap anak genius, yang membuatnya berkarakter jahat adalah lingkungannya ( orang tua dan orang dewasa sekitarnya). Dan yang memupuskan kegeniusan mereka dalam enam tahun pertama, menguap begitu saja seperti embun pagi yang diterpa sinar matahari karena perlakuan yang salah dari orang-orang dewasa sekitarnya. Bukan karena telah habisnya masa bagi kecermelangan mereka (The learning Revolution) $)^{56}$

Setiap anak "the bidden exellent" Maka Jika bakat dan potensi, keunggulankeunggulan tersembunyi anak-anak dapat dikembangkan dengan baik, secara tepat dan benar, mereka akan menjadi generasi yang dapat dibanggakan, jika sebaliknya potensi, bakat keunggulan anak tak bisa dan atau salah dalam pengembangannya (child abuse), maka akan menjadi malapetaka kehidupan. Itulah sebabnya, al-Qur'an sendiri berpesan. "Hendaklah mereka takut kepada Allah jika meninggalkan generasi yang lemah di belakang mereka, yang mereka khawatir terhadap kesejahteraannya. Karena itu, hendaklah mereka bertakwa kepada Allah dan mengucapkan perkataan yang baik. (QS. Al-Nisa (4): 9). Ayat tersebut mengisaratkan pada setiap orang tua dan atau orang dewasa lainnya agar jangan sampai meninggalkan anak dan atau generasi yang lemah. Lemah iman, lemah intellectual, lemah kemanusiaan,mental kepribadian dan lemah fisik.

Oleh karena itulah orang tua (hususnya ibu, pemilik rahim, kerahiman yg melekat pada kejadiannya) dipastikan tentang tugas essensinya sebagai pendidik utama dan pertama, memahami secara sungguh-sungguh potensi azalinya itu dan kemudian mengimplementasikannya secara nyata dan benar dalam tugas-tugas keibuannya, misalnya mewujudkan komunikasi yg efektip dengan anak2nya dengan penuh kasih sayang, mencium, memberikan kata-kata manis, mendendangkan cinta, melakukan sentuhan dan belaian-belaian lembut pada bayi-bayi mereka, anak-anak mereka. sebagaimana ungkapan Syaikh Mubammad Al-Khidir Husain "sesunggubnya ruh itu tumbuh dengan pendidikan yang lembut dan penub kasib sayang sebagaimana tubuh tumbuh dengan makanan yang sehat. Dan sesungguhnya pertumbuhan tubub mempunyai batas yg tak dapat dilewati, bahkan semakin menurun di waktu tua, namun rub akan terus tumbuh dan berkembang bingga ajal menjelang” (Megawangi, 2004: 23-39).

Cinta kasih dan kelembutan yang tulus, membuat anak-anak tumbuh sehat, jauh dari berbagai penyakit dan problema kehidupan, tumbuh optimis, penuh percaya diri dengan sarat bila ia berada bersama dengan orang-orang yang merespons kebutuhan emosional maupun intellektualnya. Rasulullah bersabda "Sesunggubnya Allob Swt

56 Fauzil adhlmim, Positive Perenting, Mizania, Bandung ,(2006) 
menyenangi kelembutan dalam semua persoalan". Juga Rasulullah Bersabda "Barang siapa yang terhalang dari kelemah lembutan berarti ia terhalang dari setiap kebaikan" (HR Muslim)

Kegembiraan menimbulkan semangat optimal, bergairah untuk belajar, Dengan dukungan dan bimbingan yang lembut, seorang anak kecil dapat merasa percaya diri untuk tidak menyerah ketika menghadapi rintangan pertama ${ }^{57}$. Diriwayatkan dari Jabir Bin Samurah ra dia berkata: aku pernah sholat zhubur bersama Rasulullah Saw, kemudian beliau keluar menuju istrinya dan akupun keluar menyertainya, lalu Rasulullah Saw disambut oleh beberapa anak kecil, maka segeralah beliau mengusap kedua pipi masing-masing mereka. Kata Jabir: Rasulullab Saw juga mengusap pipiku, lalu aku rasakan tangan beliau dingin (atau berbau) bagai bau wangi yang seolah baru beliau keluarkan dari tas penjual minyak wangi58

Dalam pandangan beberapa hadis lainnya mengisaratkan betapa Rasulullah sangat menyayangi anak-anak; Diriwayatkan dari Anas Bin Malik ra, dia berkata: Tidak pernah aku jumpai orang yang menyayangi keluarganya melebibi Rasulullah Saw. Kata Anas:Ibrabim (Putra Rasulullab Saw) disusukan pada suatu keluarga diperbukitan Madinah. Suatu ketika beliau menjenguknya bersama kami. Beliau masuk kedalam rumah yang ketika itu sedang penuh asap, karena pengasub Ibrahim tersebut seorang tukang pandai besi. Beliau kemudian menggendong Ibrahim, lalu menciumnya, kemudian beliau pulang. Kata Amru: Ketika Ibrabim wafat, Rasulullah Saw bersabda'Ibrahim adalah putraku dan dia wafat dalam usia menyusu, sunggub kelak di surga dia akan memiliki dua orang tua pengasuh yang menyempurnakan susuannya"

Di hadis lain, diriwayatkan dari Urwah Bin Zubair dan Fatimah Binti Al-Munzir Bin Zubair, keduanya mengatakan Asma Binti Abu Bakar turut berhijrah ketika dia sedang mengandung Abdullah Bin Zubari ra. Sesampainya di Quba dia melahirkan Abdullah Bin zubair, setelah itu dia mendatangi Rasulullah Saw agar beliau suapkan makanan awal dari kunyahan beliau kepada bayi itu. Rasulullah mengambil bayi tersebut dari Asma' kemudian beliau letakkan dipangkuan beliau., kemudian meminta buah kurma. Kata Aisyah; kami menanti sejenak untuk mencari buah kurma sebelum kami mendapatkannya. Lalu Rasulullah Saw mengunyah buah kurma itu kemudian beliau suapkan kedalam mulut bayi itu. Sungguh pertama kali yang masuk kedalam perut bayi itu adalah ludah rasulullah Saw. Kata Asma' setelah itu Rasulullah Saw mengusap bayi itu, mendoakannya, dan menamainya Abdullah........ ${ }^{60}$.

Stimulasi lingkungan ibarat pahatan yang bekerja membentuk sel-sel otak sehingga otak dapat berkembang dengan baik. Stimulasi yang menyenangkan,

\footnotetext{
57 kemp \&Clare Walters, Brain Games,( Karisma publishlming Group, Batam center, 2004) hlm 6

58 Op-cit. Sahlmihlm Muslim hlm. 914

59 Imam al-Mundziri, Ringkasan Shlmahlmihlm Muslim, (Pustaka amani Jakarta), hlm 914

60 Ibid. Sahlmihlm muslim 807
} 
lingkungan yang memberikan ketenangan dan penuh kasih sayang, lingkungan yang memberikan keleluasaan anak untuk bereksplorasi, akan membuat anak memiliki perkembangan otak kanan yang baik, sesuai dengan fungsi belahan otak kanan mengurusi perkembangan emosi dan kreativitas, maka anak yang mendapat stimulasi lingkungan dan pendidikan yang tepat di usia dini tumbuh menjadi anak yang percaya diri, berani tampil, mampu bekerjasama, menghargai pendapat orang lain, saling menolong dan bertanggung jawab atas perbuatan yang dilakukan"61.

Bergerak, bermain berexplorasi, tidak bisa diam, itulah seorang anak; Bermain bukan hanya menjadi kesenangan tetapi juga suatu kebutuhan yang mau tidak mau harus terpenuhi, karena jika tidak terpenuhi, menurut conny R. Semiawan ada suatu tahapan perkembangan yang berfungsi kurang baik yang akan terlihat kelak jika sianak sudah menjadi remaja ${ }^{62}$ dalam hal ini ada Sabda Rasulullah Saw "keringat anak kecil menambah kecerdasannya diwaktu dewasa" (HR AT-Tarmidzi) $)^{63}$.

Tema kasih sayang merupakan kebutuhan alami manusia, jika manusia tak bisa hidup tanpa makan dan minum, demikian halnya, manusia tak bisa hidup tanpa kasih sayang. Anak-anak sangat lebih membutuhkan kasih sayang daripada orang dewasa, karena sifat ketergantungannya, sehingga bagi seorang anak, tidak penting dan tidak begitu peka, apakah ia hidup di sebuah gubuk reot atau di sebuah istana megah, jenis pakaian apa yang dikenakan atau menu makanan apa yang dimakan, tetapi ia akan sangat peka dengan perasaan kasih sayang terhadapnya. Ibrahim Amini menjelaskan, bahwa "anak-anak yang dibesarkan dalam limpahan kasih sayang akan tumbuh menjadi anak yang mandiri dan kuat, anak-anak yang kenyang dengan kasih sayang orang tuanya, tubuhnya lebih sehat dari anak-anak yang kurang mendapat kasih sayang, anak-anak besar dalam limpahan kasih sayang, akan menjadi anak-anak yang memiliki hati yang hangat dan ketika dewasa ia telah belajar bagaimana mencintai anak-anaknya, istri, sahabat dan masyarakatnya, kasih sayang akan menyelamatkan anak-anak dari sifat kerdil, maka bagi anak-anak yang miskin kasih sayang akan tumbuh sebagai anak yang merasa dikucilkan. ${ }^{64}$ Sebaliknya, kekerasan atau dengan berbagai derivasinya ( child abuse) akan mengakibatkan penderitaan anak-anak, child abuse (salah asuh, salah asah, salah asih),yakni kondisi hubungan/lingkungan yang tidak baik di usia dini dapat mengakibatkan otak anak mengkonsumsi glucose menjadi pengalaman stress,yang traumatic bagi anak dan hal itu mengakibatkan otak anak mengorganisir ulang secara lebih permanen, sehingga meningkatkan kewaspadaan yang berlebihan, hal ini meningkatkan reaktivitas dan tekanan darah, dalam kondisi seperti ini anak

\footnotetext{
61 Musfirahlm, Bermain Sambil Belajar dan Mengasahlm Kecerdasan (Depdiknas Jakarta 2005) hlm 81

62 Conny Semiawan, opcit hlm

63 Syaihlm Muhlmammad Said Mursi, Seni mendidik, Anak, Pustaka al kautsar, Jakarta hlm 10

64 Ibrahlmim amini, Agar Tak Salablm Mendidik, Al-HLMuda, Jakarta, hlm 383-384
}

Urgensi Bermain sebagai Stimulasi Perkembangan Otak.... 
menjadi impulsif dan agressif (erickson). ${ }^{65}$. Maka bermain, bergerak yang terbimbing dari orang - orang dewasa sekitarnya, terutama orang tua, keluarga sebagai pendidik utama dan pertama, dengan penuh kasih sayang dalam ragam wujud yang mendidik, menjadi media pengembangan nilai-nilai karakter yang akan menghantarkan anakanak tumbuh dan berkembang menjadi anak yang diharapkan oleh kehidupan yg bermaslahah, kehidupan yg menghadirkan keamanan dan kenyamanan pada usia dewasanya, bukan anak-anak yang menghadirkan kehidupan yg bermasalah bagi umat.

\section{PENUTUP}

Sebagai akhir dari bahasan ini, ada 20 cara efektif untuk menghilangkan Trauma pada anak, yakni; (1). Ambil inisiatif untuk membicarakannya ( bersama anak, dan atau keluarga terdekat,tentang kejadia traumatis tersebut. (2).Yakinkan anak, bahwa keadaan pasti akan membaik dan aman baginya. (3).Dengarkan mereka, gali dan dengarkan apa yang anak ungkap, dengan penuh perhatian, tanpa mengecilkan apa yg mereka katakan, dan tidak menghakimi mereka.(4).Dorong anak untuk mengungkapkan perasaannya, tunjukkan rasa empati atas traumatic mereka, sehingga mereka bersedia mengungkap isi hati mereka. Selanjutnya hal itu penting untuk meluruskan kesalahan dan pengertian yg mungkin ada pada pikiran anaksekaligus member informasi yg benar tentang hal itu. (5). Tunjukkan kasih sayang, dalam keadaan apapun orang tua tetap menunjukkan kekuatan, untuk dapat mengatasi masalah tersebut. (6). Fokus pada hal yang positif, ajak anak untuk melihat sisi positif dari setiap peristiwa, bahwa dibalik peristiwa pasati ada hal yang positif.(7). Beri dorongan pada anak untuk bertindak, bantu anak untuk keluar dari perasaan tidak berdaya dan menumbuhkan kepedulian untuk orang lain yg juga mengalami trauma. (8). Jawab pertanyaan anak dengan sederhana, berdiskusi dengan anak, gunakan bahasa yg sederhana, tidak ber-belit2 sesuai dengan tingkat pemahaman seorang anak.(9). Buatlah rencana keselamatan keluarga, untuk membanbgun rasa aman bagi anak, jelaskan pada anak rencana2 yg dipersiapkan (dibuat)untuk keamanan seluruh keluarga.(10).Temukan cara untuk bersantai bersama anak. (11).Libatkan Anak dalam kegiatan atau tradsi yg dilaksanakan oleh keluarga. hal ini akan membuat anak merasa bahwa banyak orang lain yg akan mendukung dan menyayanginya. (12). Perhatikan adanya perubahan dalam prilaku anak, jika anak tak ingin berbicara ttg btraumatiknya, maka perhatika dg tanda2 perubahan prilaku anak. Agar dapat meminimalisir kerusakan yg lebih besar. (13). Buat Jadwal kesehatan yang rutin. bantu anak untuk meliwati rasa traumanya dg kembali pada rutinitasnya, bermain

65 MISI, opcit hlm 43 
dg teman, bersekolah, menghabiskan waktu bersama keluarga, memilihkan kegiatan yg dipili anak untuk mengisi waktunya.(14). Terapkan batasan yg konsisten dengan sabar.(15). Bangun kembali rasa aman dan percaya anak.(16)Berilah anak makanan sehat.(17). Batasi campur tangan orang lain yg tidak perlu.(18). Jangan mengkritik anak.hindari mengkritik atau meremehkan anak yang sedang menghadap traumatic. (19).Berikan Anak Waktu Untuk menenangkan diri. (20), Cari Bantuan jika trauma terlalu berat, mencari bantuan yg tepat (s//dosenpsikologi.com, tgl 22 November 2018)

\section{DAFTAR PUSTAKA}

Armstrong, Thomas. Smart Baby's Brain, Merangsang Kegeniusan Anak di Tiga Tabun Pertama, Prestasi Pustaka, Publisher, Jakarta (2003)

Auryn, Virzara. How to Create a Smart Kids, Seri Kecerdasan Anak, Penerbit Katahati (2007)

Baraja, Abubakar. Psikologi Perkembangan, Tahapan-Tahapan dan Aspek-Aspeknya dari 10 Tahun sampai Aqil Baligh, Studia Press, Jakarta (2008)

Bredekamp, Sue dan Copple. Developmentally Approriate Practise in Early Childhooh Program, USA NAECY (1992)

Bruce, T dan Maggit C. Child Care \& Education, Hodder \& Stoughton A Member of Hodeder Headline Group (1999)

Chazan, Saralea E. Profiles of Play, Assesing and Observing Structure and Process in Play Therapy, Jessica Kingsley Publishers, London and New York, (2002)

Conny R. Semiawan. Pendidikan Tinggi: Kemampuan Manusia Sepanjang Hayat Seoptimal Mungkin, Crasindo, (Jakarta, 1999).

PT. Prenhallindo, (Jakarta, 2002).

Departemen Kesehatan RI. Pedoman Deteksi Dini Tumbuh Kembang Balita, Jakarta (1992)

Dorothy, Einon. Learning Early: Panduan Perkembangan Mental dan Fisik Buah Hati Anda, Dian Rakyat, Jakarta (2002)

Essa, Eva L. Introduction to Early Childhood Education, $4^{\text {th }}$ Edition, Thomson Delmar Learning Australia, Canada Mexico (2003) 
Fawzia, Aswin Hadis. Psikologi Perkembangan Anak, Universitas Indonesia, Jakarta (1996)

Gopink, Alison. Andrew N Meltzoff. dan Patricia K Kuhl. Keajaiban Otak Anak. Mizan Mizan Media Utama, (2007)

Gunawan, Adi W. Genius Learning Strategy, PT Gramedia Pustaka Utama (2003)

Hainstoock, Elizabeth G. Metode Pembelajaran Montessori untuk Anak Pra Sekolah, Pustaka Delapratasa, Jakarta (1999)

Hidayatullah, Ahmad. Pendidikan Anak.Muslim, Pendekatan Praktis Aplikatif Berdasarkan Nilai-Nilai Islam dan Teori Pendidikan Modern, Penerbit Fikr Rabbany Group, Jakarta (2008)

Hurlock, Elizabeth B. Psikologi Perkembangan, Suatu Pendekatan Sepanjang Rentang Kehidupan, Jakarta (2000)

Perkembangan Anak, Jilid I, Edisi IV, Jakarta (1978)

Irawati, Misni. Menggali Kecerdasan Anak Melalui Bermain, (http://group,yahoo.com/ group/ppindia)

Jalal, Fasli. Stimulasi Otak Untuk Mengoptimalkan Kecerdasan Anak, Buletin Padu, Edisi 02, Jakarta (2002)

Jamaris, Martini. Perkembangan dan Pengembangan Anak Usia Taman Kanak-Kanak, Gramedia Widiasarana, Jakarta (2006) Jensen, Eric. Memperkaya Otak, Cara Memaksimalkan Potensi Setiap Pembelajar, PT Indeks, Jakarta (2008)

Labinowicz Ed. The Piaget Primer Thingking, Learning Teaching, Addison-Wesley Publising Company, California (1980)

Lily, Djokosetio Sidiarto. Perkembangan Otak dan Kesulitan Belajar Pada Anak, UI Press (2007)

Mayke S. Bermain, Mainan dan Permainan untuk Pendidikan Anak Usia Dini, PT Gramedia, Jakarta (2001)

Montolalu dkk.Bermain dan Permainan Anak, Universitas Terbuka, Jakarta (2005)

Musfiroh, Tadkiroatun. Bermain Sambil Belajar dan Mengasah Kecerdasan, Depdiknas, Jakarta (2005)

Paul, Henry Musem Dkk. Perkambangan dan Kepribadian Anak, Edisi Ke 6, Penerbit Arcan, Jakarta (1994) 
Perry, Jane. Outdoor Play Teaching Strategies with Young Children, Teachers College Press, Teachers College, Columbia University, New York and London (2001)

Prasetyono, Sunar. Membedah Psikologi Bermain Anak, Penerbit Think, Yogyakarta (2007

Rochmat, M N. Peningkatan Mutu Pendidikan Anak Usia Dini Melalui Pembelajaran Holistik, Buletin Padu, EdisiKhusus, Jakarta (2005)

Santoso, Sugeng. Pendidikan Anak Usia Dini, Penerbit Citra Pendidikan, Jakarta (2004).

Santrock, John W. Life Span Development, Times Mirror Higher Education Group (1997)

Sarjunani, Nina. Pendidikan Anak Usia Dini Sebagai Investasi Sumber Daya manusiaRPJMN 2004-2009 \& Draf RPJPN 2005-2025, Buletin Padu, Edisi Khusus, Jakarta (2005)

Shapiro. Mengajarkan Emotional Intelligence Pada Anak, (Terjemahan Alex Tri Kancono), Jakarta (2008)

Sears, William. Successful Child, Embun Publishing, Jakarta (2006)

Silberg, Jackie. Brain Games for Toddlers, Penerbit Erlangga, Jakarta (2004)

Sinolungun. Psikologi Perkembangan, Perkembangan Peserta Didik, Gunung Agung, (2001)

Slee, Fhilip and Rosalyn Shut. Child Development: Thinking About Theories, Oxford University Press Inc, London (2003).

Sudiarto, Kusumoputro dan Lily Djokosetio. Belajar \& Pola Pikir Berbasis Mekanisme Otak, Penerbit Universitas Indonesia (2008)

Suyanto. Konsep Dasar Pendidikan Anak Usia Dini, UNY, Yogyakarta (2003)

Taugada, Jadmya. Memahami Otak, PT Kompas Media Nusantara, (2003)

Time Life Asia. Developing Your Child's Potential, Success Parenting (Printed in Cina, 2000)

Warner, Penny. Play \& Learn (150 Aktivitas Bermain dan Belajar Bersama Anak), Penerbit PT Elex Media Komputindo, Kelompok Gramedia, Jakarta (2004) 